\title{
Digital Zakat Fundraising in Times of Covid-19 Pandemic: Evidence from BAZNAS, Indonesia
}

\author{
Zulfikar Hasan ${ }^{*}$, Kamiluddin ${ }^{2}$ \\ ${ }^{1}$ Sekolah Tinggi Agama Islam Negeri Bengkalis Riau, Indonesia \\ 2 University of Malaya, Malaysia
}

Article History

Received: November, $22^{\text {nd }} 2021$ Revised: December, $24^{\text {th }} 2021$ Accepted: January, $3^{\text {rd }} 2022$

\begin{abstract}
*Corresponding

author:

E-mail:

zulfikarhasan61@gm

ail.com

This research analysed the impact of COVID19 on zakat institutions. The COVID19 outbreak forced policymakers to issue various innovations to manage the pandemic consequences. BAZNAS of the Republic of Indonesia has introduced its digital zakat platforms to facilitate muzaki in performing zakat. The collection of zakat funds at BAZNAS of the Republic of Indonesia has increased despite the COVID19 pandemic. This study employed a qualitative method by analyzing primary and secondary data. The results of this study concluded that the role of digital technology during the pandemic to collect zakat funds greatly facilitates muzaki. Besides that, it has received full support from the MUI (Indonesian Ulema Council) and the government. Hopefully, typical research like this that can raise more themes about the role of zakat during the COVID19 pandemic.
\end{abstract}

Keywords COVID19, Digital Technology, Zakat Funds. BAZNAS, Indonesia

\section{Introduction}

Indonesia is a country with the largest Muslim population in the whole world. At present, it is estimated that the number of Indonesian Muslims is 207 million. With the potential that Indonesia has, of course, Indonesia can improve the economy of the Ummah. Such as Islamic finance, Islamic banking, and the collection of zakat funds that can have a good impact on Indonesian society (Bakar, Rahim, \& Rahman, 2007). Among the wisdom that zakat is prescribed is to realize equity in the economy. As one of the assets of Islamic economic institutions, zakat is a potential source of strategic funds for efforts to build the welfare of the people. Therefore, the Qur'an gives signs so that the collected zakat is distributed to mustahiq (people who are truly entitled to receive zakat) (Rofiq \& Ahmad, 2012).

How to cite:

Zulfikar Hasan, \& Kamiluddin, K. (2021). Digital Zakat Fundraising in Times of Covid-19 Pandemic: Evidence from BAZNAS, Indonesia . Journal of Islamic Economic and Business Research, 1(2), 202-215.

https://doi.org/10.18196/jiebr.v1i2.1 
In the past, zakat had to be done conventionally by coming directly to the zakat institution and directly meeting the Amil zakat. Along with the development of the times, zakat can also be done online/digitally. This digital zakat trend has developed since last year, where the COVID-19 pandemic forced people to reduce physical contact and activities outside the home. So that the Amil zakat institutions issue a practical way of giving zakat that can be done from home, namely via digital.

Paying zakat digitally provides many conveniences and benefits. In addition to being more simple and practical, people do not even need to leave the house anymore by paying it via the zakat institution platform. You can tithe safely, comfortably, and easily. In addition, there are several benefits that you can get if you do digital zakat:

First, it can be done anywhere. By paying zakat via digital, you no longer need to be confused because your house is far from a mosque or a zakat institution. You can easily do it on your phone. Even if you are in the office or on a trip, you only need to open the available platform and fill in your bio, and immediately pay zakat. Second, guaranteed security. On every platform of zakat institutions, they certainly have digital finance to make zakat collection and management more efficient, transparent, and massive. You no longer need to be afraid that your zakat will not be distributed because, with digital zakat, those who receive zakat will be notified clearly and transparently (Fifi, 2015).

Zakat itself is a form of worship with sincerity in its style, namely as a form of worship with two dimensions (Rais, 2009). Not only does it have a social dimension, but zakat also has an economic dimension which is very important for realizing the welfare of the people. Therefore, zakat always becomes a topic to be discussed to realize social justice in people's lives.

Before the COVID-19 virus pandemic, the recipients of zakat funds were specifically only for 8 groups, as confirmed in Surah At-Taubah. However, along with the development and changing times, scholars agree that Islam is a religion of humanity, which is compatible with time, meaning that the rules and laws in Islam were created for the benefit of mankind. So, under current conditions, zakat is used as an instrument of the source of funds in the grip of COVID-19. However, the use of zakat funds for these conditions is carried out freely but must be based on clear criteria so as not to get out of the zakat function itself (Saputra, 2020).

Zakat can be focused on productive activities since the benefits can be felt continuously. The implementation of the distribution of zakat funds can be done in the form of zakat is distributed to maintain individual income in the poor group, zakat which has been allocated within $50 \%$ can be allocated in the form of financing productive activities for the poor or underprivileged groups. For example, financing activities and productive skills training or providing business capital (Maulana, 2019).

Utilizing zakat fund collection technology makes the management and distribution of zakat funds by the National Zakat Agency (BAZNAS) to be more optimal. From the collection side, it is targeted that zakat funds collected through digital can reach 30 percent of the total funds raised in 2021 (Ariyani, 2019). Currently, the use of renewable technology in the era 
of revolution 4.0 is increasingly being carried out. Various industrial sectors, including the financial industry, must adjust to these changes so as not to be left behind. The BAZNAS is no exception as a financial institution that has adopted the developing technology for the last few years.

Since 2016, Baznas has started a digital service for collecting zakat funds. Since then, the collection of zakat funds through digital platforms has continued to increase every year. This is because digital services are very useful to make it easier for muzaki to donate their zakat. Besides, through digital platforms, the total funds constantly increase (Husen, Husaeni, Jamil, \& Saepudin, 2019).

At the end of 2019, the world was hit by an outbreak of coronavirus or COVID19, which paralyzed the world economic system, including Indonesia. The Indonesian economic sector feels a sizable impact, both in the micro and macroeconomy (Rozalinda, 2014).

Continuously now, the positive number of COVID19 nevertheless displays an increasing trend. More further than 1 million positive cases of corona have happened in Indonesia, with the number of recovered cases reaching 900 thousand. The mortality rate shows a downwards trend in percentage (Rialita, 2018). Meanwhile, on the other hand, we are also dealing with a slowdown in Indonesia's economic growth. In the past decade, this is the first time Indonesia's economic growth has been below the three percent rate, where the economy only grew 2.97 percent in the first quarter of 2020, even though this figure occurred when the COVID19 pandemic was only at an early stage of development, currently already on the slope of the curve and moving towards the top of the COVID19 spread curve.

With the above conditions, the contribution and role of all components of the nation are very important so that the negative impacts of the COVID19 pandemic can be properly mitigated and overcome. The state cannot be alone in this. The support and collaboration of various parties are needed so that all resources owned by this nation can be utilized properly. One of the institutions that play a role in efforts to deal with the impact of COVID19 is the zakat institution (Rahman, 2007).

The collection of zakat funds through the BAZNAS of the Republic of Indonesia has gone through a fairly long phase. Eventually, a digital system has emerged, which is currently widely used in various sectors, especially the Islamic banking sector and Islamic finance. The collection of zakat funds will experience problems during a pandemic like this if there are no innovations made or launched by BAZNAS (Ariyani, 2019).

The COVID19 pandemic has made policymakers make various kinds of innovations and facilities for the community, especially in the field of finance and zakat collection. BAZNAS has issued digital technology to make it easier for Muzzaki to pay zakat using only digital technology (Karim \& Muhammad, 2021). 


\section{Literature Review}

\subsection{The Concept of Technology Digital}

The development of technology in life starts from a simple process in everyday life until it reaches the level of satisfaction as an individual and a social being. Technological advances continue to develop, ranging from agricultural technology, industrial technology, information technology, and communication. The development brings various impacts in the life of society, nation, and state where every individual is interested in using and taking advantage of each of these developments (Santoso, 2018).

In the 2000 era, technological advances developed rapidly, information technology and telecommunications became the trend of every individual's life. Activities start to be made easier with the various conveniences offered, ranging from communication, information, transactions, education, entertainment to even the most personal needs that can be served with this technology. Related to this technological development in several countries, Europe has launched the concept of "Industry 4.0", this digital transformation concept utilizes new digital technology as a model for activities and transactions so that the internet and other information technology industries emerge. The wave of digital system transformation is a common element that encourages every activity to take advantage of digital media as the main means so that digital transformation becomes a pillar of industrial policy in several countries (Dragan, 2016).

Utilizing information and telecommunications technology (ICT) as much as possible is necessary to gain new knowledge and create new values by making the connection between "man and machine" and between "real world and the virtual world" as an effective and efficient way to solve problems in society, creating a better life for people, and maintaining healthy economic growth. To realize such a society through digitization, it is important to overcome challenges through the involvement of various stakeholders at various levels to share a common vision for the future (Rahman \& Aidil, 2021).

Table 1. Key Statistics 2015-2019 (billion rupiah)

\begin{tabular}{|c|c|c|c|c|c|}
\hline Collection & 2015 & 2016 & 2017 & 2018 & 2019 \\
\hline Zakat Maal Individual & $1,983.4$ & $2,843.7$ & $2,785.2$ & $3,302.2$ & $3,951.1$ \\
\hline Zakat Maal Institution & 157.8 & 620.5 & 307.0 & 492.4 & 306.7 \\
\hline Zakat Fitr & 168.1 & 274.0 & $1,101.9$ & $1,112.6$ & $1,406.1$ \\
\hline Infaq/Sadaqah and CSR & $1,177.3$ & $1,001.5$ & $1,764.9$ & $2,517.4$ & $3,383.6$ \\
\hline $\begin{array}{l}\text { Other Socio Religious } \\
\text { Funds }\end{array}$ & 163.8 & 277.6 & 265.3 & 692.9 & $1,173.1$ \\
\hline Collection Growth (\%) & 10.6 & 37.5 & 24.1 & 30.4 & 26.0 \\
\hline $\begin{array}{l}\text { Allocation to Collection } \\
\text { Ratio (ACR) (\%) }\end{array}$ & 61.6 & 58.4 & 78.1 & 83.8 & 84.9 \\
\hline ACR Category & $\begin{array}{c}\text { Fairly } \\
\text { Effective }\end{array}$ & $\begin{array}{c}\text { Fairly } \\
\text { Effective }\end{array}$ & Effective & Effective & Effective \\
\hline
\end{tabular}

Sources: National Zakat Statistic 2019

All digital and electronic activities with data as their main role, individuals are no longer limited to space and time. They can make transactions electronically anywhere, with anyone 
and anytime. Digital money plays an important role, such as salaries being given digitally, shopping and transactions by digital means, and even transaction activities are also transferred digitally because they are faster, more effective, and efficient. Digital transactions involve several third parties as a medium for intermediary transactions, can Bank in real or virtual form. The transaction process takes place through various activities such as sales, purchases, auctions, payments, and orders made through such as e-banking, SMS-banking, internet banking, e-money, and other payments through outlets that have payment access facilities (Putrawangsa \& Hasanah, 2018).

Digital technology is an information technology that prioritizes activities carried out in a computer/digital manner rather than using human labor. But more tend to the fully automated and sophisticated operating system with a computerized system/format. Digital technology is just a very fast calculating system that processes all forms of information as numerical values. Technological developments have brought changes to the quality and efficiency of the data to be generated and transmitted. Images become clearer due to better quality, more efficient capacity, and faster delivery (Mayumi, 2018).

Digital technology will continue to evolve. In the future, the development of this technology will be influenced by three things, namely digital transition, network convergence, and digital infrastructure. Network convergence is the efficiency and effectiveness of communication networks that can be used, such as telephone, video, and communications both at home and in companies. The higher the need for network convergence, the more technology will change towards this need (Rialita, 2018).

\subsection{The Concept of Zakat}

The occurrence of zakat for the economic development of the people Islam is a very important part because utilizing zakat, a welfare distribution mechanism in embodied Islamic concept. In zakat, there is a movement of wealth from the capable to the poor and entitled to receive it. The main purpose of zakat is to welfare people. In the quotation of the Koran Surah al-Ma'un, it is explained, "Do you know (person or group of people or country) who denies religion... ". So a country that denies religion is a state that doesn't take care of its poor. The verse mentions, a characteristic of piety individuals, institutions, and the state are in favor of that marginalized because the factor of piety will be disturbed if disturbed economic problems. Islamic teachings are not only a problem spiritual but also material (Abdurachman, 2010).

One of the things that support the welfare of life in the world and supports life in the hereafter is the existence of socio-economic welfare. This is a set of alternatives for the welfare of Muslims from poverty and squalor. For this reason, it is necessary to establish Islamic social institutions to overcome these social problems. In this connection, zakat can function as a source of socio-economic funds for Muslims, meaning that the utilization of zakat managed by the Amil Zakat Agency is not only limited to certain activities based on a conventional orientation but can also be used for economic activities of the people, such as in poverty and unemployment alleviation programs by providing productive zakat to those who need it as business capital (Fifi, 2015). 
The target recipients of zakat, as mentioned in the Al Quran, consist of eight groups, namely: indigent, poor, amil (zakat officers), converts, liberating slaves, people in debt (gharimin), fi sabilillah (jihad), and ibnu sabil. The ideal zakat management cannot be separated from the role of the government. Al Quran implicitly states that state involvement in zakat management is very much needed by (Fakhrur, 1981). When interpreting the word "amil" in At Taubah: 60 says that the word implies territory (power). Besides, the word "khudz" in Sura At Taubah: 103 is an order to take zakat. The order can be counterproductive if it is carried out without going through the government, either directly or under government supervision. Because zakat is mandatory, the collection of zakat from the rich to be given to the poor can be done either voluntarily or not (Rialita, 2018).

\subsection{Collection of Zakat Funds}

Management of zakat, according to Law no. 23 of 2011, is an activity of planning, implementing, and coordinating the collection, distribution, and utilization of zakat. From the scope of this definition, collecting zakat is one of the two core tasks of zakat management institutions. Besides the efficient and professional utilization (distribution) of zakat funds, collection activities should also receive special attention. The success of collecting zakat at the Zakat Management Institute (LPZ) is inseparable from the success of zakat management in general. LPZs that are successful in managing funds are those that can carry out their functions properly. In other words, a successful LPZ is an LPZ that can maintain and maintain public trust, carry out activities to collect zakat funds, manage and internal finance, utilize zakat funds effectively and efficiently, and prioritize institutional management with professional management (Hasan, Distribution Of Zakat Funds To Achieve SDGs Through Poverty Alleviation In Baznas Republic Of Indonesia, 2020)t.

Indonesia Magnificence of Zakat States that the successful management of zakat funds by zakat management institutions (LPZ) cannot be separated from the five areas that LPZ assessment, namely: sharia compliance, legality, and institutions; financial performance; economic performance; the performance of social legitimacy and socio-political performance (Zakat, 2011).

Zakat has a very strategic role in efforts poverty alleviation or economic development. Unlike financial resources for other development, zakat does not have any repercussions except pleasure as a reward from Allah alone. However, it does not mean that zakat does not have a control system. The economic empowerment of the people can be developed along with the distribution of zakat funds to those who are entitled to receive them. With zakat funds, poor people will get a more decent life and be able to develop businesses (Izzudin, Nadirah, Yazmin, \& Nordin, 2021).

\subsection{Zakat and the COVID19 Pandemic}

Siti Fariza, in her research, highlighted the need to utilize rules ad-darürah tuqaddaru biqadarihâ in distributing zakat for disaster victims. So that the use of zakat is not at will and is always within limits outlined by the law, and this paper became the basis of the author's research approach on the need for limits on the utilization of zakat to undertake the COVID19 pandemic (Siti, 2018). 
Atep Hendang Waluya also wrote about the meaning of fî sabilillah, in which he concluded that three groups interpreted fi sabilillah in various ways, narrow opinion, broad opinion, and moderate opinion. The author's research is follow-up research that tries to implement the results of the efforts that have been made by researchers into the technical realm, especially in the response to COVID19 (Atep, 2017). Mohd Rilizam Rosli has also reviewed the implementation of zakat distribution for riqâb but does not specifically relate it to the pandemic situation, leaving space studies that the authors make the reasons for the author's research (Mohd, 2018).

The impact of covid-19 has a very strong impact on the economy of the community. The economy of the community at the time of this pandemic resulted in a lot of efforts from the community being hampered, the economic competitiveness of the community was weakening, employees were laid off, transportation services also decreased, so with this condition resulted in decreased people's income even none at all. This situation has an impact on increasing the number of poor people. The community is very vulnerable to be the group most affected by the COVID19 pandemic (Putrawangsa \& Hasanah, 2018).

The utilization of zakat funds for disaster purposes can be distributed to those in need, as is currently happening in the Covid-19 pandemic disaster. The Covid disaster has paralyzed the people's economy, which is vulnerable to an increase in the number of poor people. So that the victims of the Covid disaster can be categorized as zakat in fakir asnaf and poor (Hudaefi, 2021).

In Asep Suryahadi's research, the impact of Covid-19 will result in a weakening of the economy. The impact of covid will result in a drastic increase in the poverty rate. The hypothesis generated in this study says that the impact of Covid has an impact on the decline of economic growth up to $4 \%$. The same thing was conveyed that 1.3 million people will fall simultaneously into poverty (Asep, 2020).

The realization of the economic emergency program carried out by BAZNAS RI to meet basic needs, namely maintaining the basic needs of the community. The government has made policies regarding social distancing and the imposition of large-scale social boundaries to break the chain of spreading the covid-19 virus. BAZNAS RI has also collaborated with daily workers such as online motorcycle taxis, public transportation drivers, and others to cooperate with BAZNAS in carrying out environmental cleaning such as spraying disinfectants in public areas and for this cooperation, BAZNAS provides wages to them. BAZNAS has also realized an economic emergency program with prioritizing zakat fitrah funds for those families affected by Covid-19. Baznas also provide direct assistance to people in need to maintain their purchasing power during this pandemic (Nasional, 2020).

This research tries to see the effectiveness of fundraising during the covid19 period that has been carried out by BAZNAS RI. In addition to BAZNAS, several institutions have implemented digital payments in paying zakat. Consequently, the author tried to analyze the ability of Baznas to provide the best service for digitally collecting zakat funds to the public. 


\section{Research Methodology}

\subsection{Research Design}

The research design was a form of analysis that developed and formulated several important points accordingly. The author used a non-experimental design, and this design was exploratory and descriptive. It can be concluded that the role of digital technology is an important point in this research and brought a good impact for mustahik and muzaki during the COVID-19 pandemic for collecting zakat funds. In addition, a qualitative method was applied in data analysis to develop the formulation of findings.

\subsection{Data and Sample}

Data was collected from an analysis of the use of digital technology during the COVID-19 pandemic. This research has been conducted since the COVID19 pandemic in Indonesia as well as how the innovations made by BAZNAS RI make it easier for Muzaki in collecting zakat funds. How is the development of digital technology from day to day to attract public interest? The data used is a qualitative data type, where researchers get observation data and from the internet what digital payments have been made by Baznas and what institutions have collaborated with Baznas.

\subsection{Data Analysis Method}

The data collection techniques were carried out through library research. Apart from that, it also applied descriptive analysis research. This study used primary and secondary data. The Primary data were obtained through direct observation to BAZNAS RI to get an initial picture. Besides that, the primary data also came from the analysis from the website (Sugiyono, 2015) through the observations for 2 months. The observations focused on the internet and related references, especially the Baznas website and news sources from the internet.

\section{Results and Discussion}

In supporting operational activities, BAZNAS Republic of Indonesia is supported by information and communication technology, from simple technology to the internet and digital technology. Simple information and communication technology are ranging from bulletin boards, brochures, banners, telephone information (call centers), SMS centers, contact persons, emails, WhatsApp, Twitter, Facebook, and website. From field observations, BAZNAS Republik Indonesia has information and communication technology to collect and distribute zakat funds, including announcement boards, brochures, banners, call centers, emails, and websites.

Talking about digital technology in the collection of zakat funds carried out by BAZNAS of the Republic of Indonesia during the COVID19 pandemic has had a lot of positive impacts on the zakat fundraising system rather than muzaki.

However, according to the author's opinion, there are several success factors in collecting zakat funds during the COVID19 pandemic, such as; digital technology innovation, 
management, and regulations from the government regarding the permissibility of collecting zakat funds through digital technology.

The role of digital technology during a pandemic like this has had a good impact on mustahik and muzaki. Through BAZNAS the Republic of Indonesia, several policies have been implemented. This innovation is realized with various strategic steps as a form of adaptation to accommodate the needs of the community in distributing zakat, donations, and alms (ZIS) during the pandemic.

The growth of ZIS collection through digital channels from January to November reached 284 percent. Baznas is aggressively innovating and cooperating with many e-commerce companies during a pandemic to make it easier to pay zakat to muzaki. Also added from the retail sector, the Zakat Collection Unit (UPZ), CSR, and corporate zakat. In facing the new normal, drastic adaptations are needed in society to accept changes in habits as an effort to prevent transmission of COVID19.

From January to November 2020, the ZIS and DSKL funds collected reached 9 Trillion (still far from the zakat potential of 230 Trillion), or an increase of 70 percent compared to the same period in 2019.

When the number of muzaki affected by the economic crisis due to Covid-19 increases, so that the number of people who reach the nishab of zakat decreases, both employers and employees, then zakat earnings are expected to decrease. However, in these conditions, many new muzaki have appeared who are moved to help deal with COVID-19.

During the period from January to May 2020, where half of this period was lived with unusual conditions due to the Covid-19 pandemic, the performance of Baznas ZIS and DSKL collection was very good. The indicator is the monthly growth of not less than $30 \%$ from the same month in the previous year. Likewise, the muzaki growth rate reached $176 \%$.

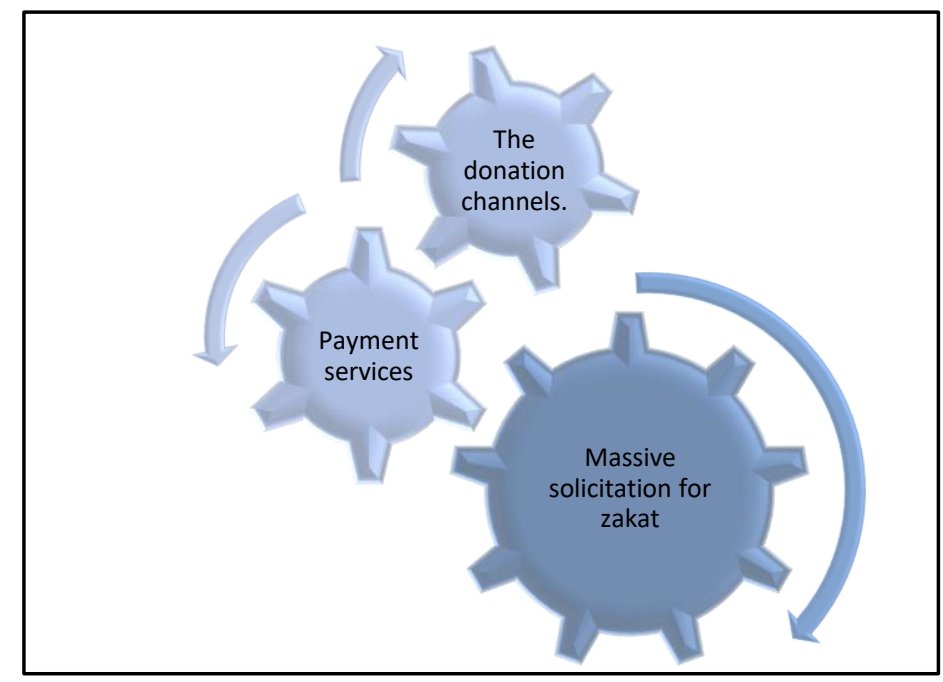

Figure 1. Innovation in zakat collection through BAZNAS Republic of Indonesia

The three of them are strategies developed at Baznas as well as other zakat institutions during the Covid-19 crisis by developing good campaigns or communication by utilizing 
online media platforms, WhatsApp, Facebook, Twitter, and so on, containing invitation posters and BAZNAS assistance programs during the pandemic. For satisfying service, including zakat pick-up service. The success in opening the donation channel is the last element that will affect the increase in the number of collections during this pandemic by opening various channels for zakat, infaq, alms donations through digital channels. Through this service innovation, the collection of funds from ZIS and Other Religious Social Funds (DSKL) amid a pandemic continues to increase significantly.

The contribution of collecting zakat via digital channels in Indonesia is estimated to reach $30 \%$ in the future. In addition to digital technology, strengthening zakat institutions is carried out through cooperation with multilateral institutions.

The use of information technology to support better zakat management is urgently needed. Because, with the use of IT, the management of zakat that is trustworthy, professional, transparent, accountable, and takes into account sharia compliance can be realized. A better information system is expected to increase public trust in the amil zakat institution.

The National Zakat Agency (Baznas) has also developed a technology system that enables optimal management and distribution of zakat. Digital processes boosted zakat collection sharply. Until 2019, it is predicted that zakat management will increase by $30 \%$.

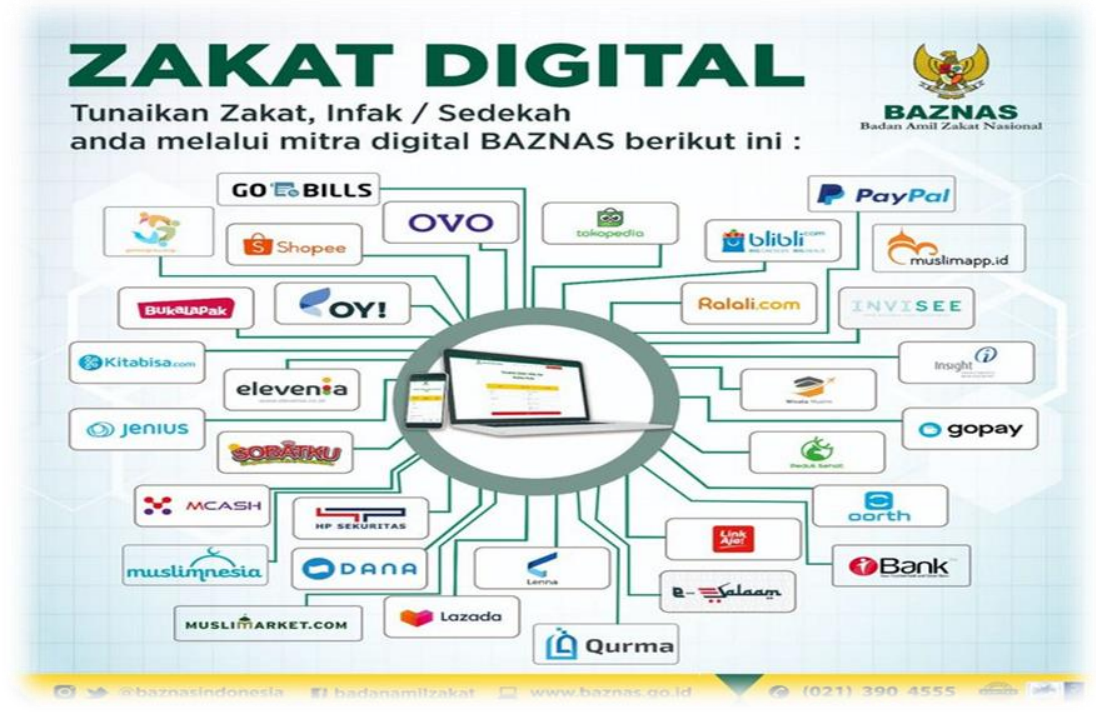

Figure 2. Digital Zakat Payment Application

Until now, there have been many digital payment applications collaborating with Baznas for zakat payments. Apart from those mentioned earlier, there are also OVO, Dana, Link Aja, and others. With the many benefits on offer, then the internet or internet-based media offer a more lucrative offer. This development will be responded to by the increasing number of companies, agencies, institutions, or organizations that use the media to socialize their units, as well as the products or services offered.

Besides, currently, BAZNAS is following MUI directives, and the government has opened an online zakat fitrah service, namely on the baznas.go.id/zakatfitrah website, Kitabisa at 
Kitabisa.com/zakatfitrah, Tokopedia at bit.ly/zakat-fitrah-tokopedia, and Shopee at bit.ly/zakat-fitrah-shopee.

Digital zakat is the 3rd pillar of the Baznas zakat program and has five platforms as the backbone that can be developed in the Baznas digital zakat program.

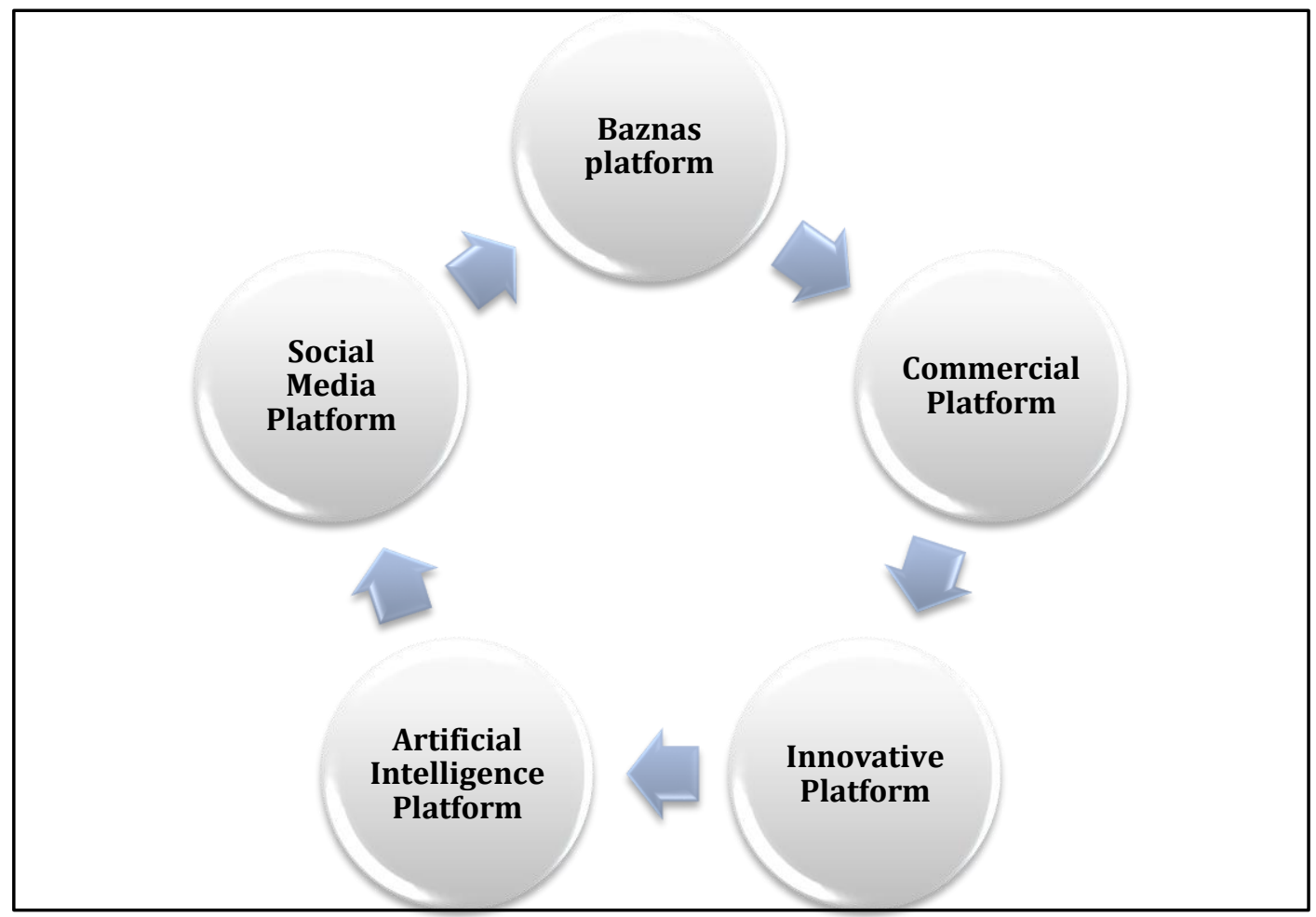

Figure 3. Five Pillars of Baznas Digital Zakat

First, the Baznas platform is to support an increase in the ease of giving zakat, and the Baznas website is one of the donation channels. The Baznas application on the Playstore makes it easier for people to get information and pay zakat directly from their cellphones. Second, commercial platforms. Baznas has collaborated with several online store providers with online shopping facilities to facilitate zakat. Several online providers such as Tokopedia, Bukalapak, Kitabisa, and several others, are still working with Baznas. Third, social media platforms are used by Baznas as a means of communication and a tool for the community to distribute donations to Baznas. The starting from social media advertising, collaborating with partners to develop a virtual season in Saki on Line and Lena on the play store. Fourth, innovative platforms. Currently, in minimarkets, digital machines are often used for ZIS, even for qurban. Baznas will develop various innovative digital channels for donation channels. And fifth, the artificial intelligence platform as Baznas's way of campaigning for ZIS through Baznas not only to the general public but also to the community according to their behavior and the information needs.

Our recommendation as a researcher to the Baznas Institute is to only be able to apply zakat fund collection not through Android but also through internet banking. Wider cooperation with bank institutions and non-bank institutions to further expand the collection of zakat funds. Not only in collaboration with central institutions but also in regional institutions. 
Our recommendation as a researcher to the Baznas Institute is only to be able to apply zakat fund collection not through Android but also through internet banking for wider cooperation with bank institutions and non-bank institutions to expand further the collection of zakat funds, not only in collaboration with central institutions but also in regional institutions. In this research, narratives and observations were described accordingly. The results of the observations have been analyzed and given a narration following the theories that support the research.

\section{Conclusion}

With the BAZNAS online zakat, it is easier for people to pay their zakat even during the COVID-19 pandemic, which cannot be predicted when it will end. BAZNAS is also committed to distributing zakat collected online for mustahik in need through program institutions owned by BAZNAS.

BAZNAS of the Republic of Indonesia has also conducted various collaborations with digital platforms to facilitate the inclusion of collecting zakat funds in addition to making it easier for people to pay zakat during the COVID-19 pandemic. In the future, the development of digital technology will be growing rapidly, considering that Indonesia is the largest Muslim country in the world. With this strength, it is hoped that the government can take the maximum role in collecting and distributing zakat funds estimated at nearly 300 trillion rupiahs. In general, the role of digital technology is very important and plays a big role in the COVID-19 pandemic, apart from helping the government to break the chain of the COVID-19 pandemic in Indonesia.

\section{References}

A. B., I. S., \& Ibrahim. (2017). Malaysian Islamic quality management system MS1900: An implementation steps at Malacca Zakat Center. Humanomics, 239-254.

A. H. (2017). Analisis Makna Fi Sabilillah dalam QS Taubah ayat 60 dan Implementasinya dalam Perekonomian. Jurnal Rausyan Fikr, 1407-1418.

A. S. (2020). The Impacr of COVID19 outbreak on Poverty: An Estimation for Indonesia. Jakarta: SMERU Research Institute.

Abdurachman. (2010). Zakat Dalam Dimensi Mahdhah dan Sosial. Jakarta: Raja Grafindo Persada.

Ariyani, N. (2019). Zakat as a Sustainable and Effective Strategy for Poverty Alleviation: from the Perspective of a Multi-Dimensional Analysis. International Journal of Zakat, 88-106.

Ascarya. (2021). The role of Islamic social finance during Covid-19 pandemic in Indonesia's economic recovery. International Journal of Islamic and Middle Eastern Finance and Management.

Bakar, A., Rahim, N. B., \& Rahman, A. (2007). A Comparative Study of Zakah and Modern Taxation. Journal of King Abdulaziz University, 20-34.

Chairy. (2020). Integrating trust, religiosity and image into technology acceptance model: the case of the Islamic philanthropy in Indonesia. Journal of Islamic Marketing, 0.

D. V. (2016). The Future Concepts and New Visions of Factory of The Future Developments. International Scientific Conference on ICT and E-Business Related Research (pp. 293298). London: Other. 
F, S. (2018). Aplikasi Kaedah Fiqh Al-Darurah Tuqaddar Baiqadariha dalam Agihan Zakat untuk Mangsa Banjir. Jurnal Infad, 1-15.

F. N. (2015). Pengumpulan dan Pendayagunaan Zakat, Infak dan Sedekah. Jurnal Zakayt dan Wakaf, 279-295.

F. R. (2017). Tafsir al-Kabir wa Mafatih al-Ghaib. Beirut: Dar Elfikr.

Hasan, Z. (2020). Distribution Of Zakat Funds To Achieve SDGs Through Poverty Alleviation In Baznas Republic Of Indonesia. AZKA International Journal Of Zakat \& Social Finance (AZJAF), 25-43.

Hasan, Z. (2021). The Effect of CAR, ROA, NPF Aand BOPO On Net Operating Margin (NOM) In Indonesian Shariah Banking. Proceedings of 2nd Annual Conference on IHTIFAZ: Islamic Economics, Finance, and Banking (ACI-IJIEFB) 2021 (pp. 41-60). Yogyakarta: Universitas Ahmad Dahlan Yogyakarta.

Hasan, Z. (2021). The Effect Of Economic Growth and Human Development Index on Poverty in Indonesia. Journal of Economics and Sustainability (JES), 42-53.

Hasan, Z. (2021). THE EFFECT OF PROFIT SHARING FINANCING AND RECEIVABLES TOWARDS TOTAL ASSETS IN ISLAMIC BANKING: CASE STUDY IN BNI SYARIAH. Labuan e-Journal of Muamalat and Society [LJMS], 62-74.

Hasan, Z., \& Saifunnajar. (2021). The Impact of Gross Enrollment Ratio (GER) of Tertiary Education in Indonesia on the Literacy and Inclusion Index: A Case Study Of Islamic Finance in Indonesia. Al-Amwal: Jurnal Ekonomi dan Perbankan Syariah, 181-202.

Hudaefi, F. A. \& Beik, I. S. (2021). Digital zakāh campaign in time of Covid-19 pandemic in Indonesia: a netnographic study. Journal of Islamic Marketing, 498-517.

Husen, D. S., Husaeni, U. A., Jamil, I., \& Saepudin, D. (2019). The Variables that Affect Compliance of Muslim Merchants for Zakat Maal in the District of Cianjur. International Journal of Zakat, 78-87.

Izzudin, M., Nadirah, F., Yazmin, F., \& Nordin, B. (2021). Merakyatkan Institusi Zakat Menurut Perspektif Maqasid Syariah. AZKA International Journal Of Zakat \& Social Finance (AZJAF), 91-104.

Karim, \& Muhammad. (2021). Determinants of digital zakat payments: lessons from Indonesian experience. Journal of Islamic Accounting and Business Research, 362-379.

M. A. (2013). Ekonomi Islam : Sejarah, Konsep, Instrumen, Negara dan Pasar. Jakarta: Raja Grafindo Persada.

M. A. (2021). ICT-based collaborative framework for improving the performance of zakat management organisations in Indonesia. Journal of Islamic Accounting and Business Research, 887-903.

M. F. (2018). Society 5.0: Aiming For a New Human-Centered Society. JEF Journal Japan Spotlight, 47-50.

Malik, B. A. (2019). Philanthropy in Practice: Role of Zakat in the Realization of Justice and Economic Growth. International Journal of Zakat, 64-77.

Maulana. (2019). Implementasi Pendistribusian Zakat Produktif dalam Meningkatkan Ekonomi Masyarakat. Tadbir : Jurnal Manajemen Dakwah, 16-29.

Mohd. (2018). Asnaf Zakat Distribution Mechanism in Today's World. International Journal of Academy Research in Business and Social Science, 1902-1102.

Putrawangsa, \& Hasanah. (2018). Integrasi Teknologi Digital Dalam Pembelajaran di Era Industri 4.0. Jurnal Tatsqif, 42-54.

R. A. (2007). A Comparative Study of Zakah and Modern Taxation. Journal of King Abdulaziz University, 20-34.

R. N. (2018). Era Revolusi Industri 4.0, Pembelajaran PT Harus Lebih Inovatif. Jurnal Tabularasa PPS, 130-139.

Rahman, \& Aidil. (2021). A framework to analyse the efficiency and governance of zakat institutions. Journal of Islamic Accounting and Business Research, 43-62.

Rais, I. (2009). Muzzaki dan Kriterianya dalam Tinjauan Fiqh Zakat. Al-Iqtishad, 91-106. 
Rofiq, \& Ahmad. (2012). Dari Normatif ke Pemaknaan Sosial. Yogyakarta: Pustaka Pelajar. Rozalinda. (2014). Ekonomi Islam; Teori dan Aplikasinya pada Aktivitas Ekonomi. Jakarta: Rajawali Press.

S, S. (2002). Faktor-Faktor Penentu Tingkat Kemiskinan Regional di Indonesia. Economic Journal of Emerging Markets, 87-102.

Saputra. (2020). Zakat Sebagai Sarana Bantuan Bagi Masyarakat Berdampak Covid-19. AlIjtima'i : International Journal of Government and Social Science, 1-15.

Siswantoro, D., \& Nurhayati, S. (2019). Preparedness Response of Indonesian Tax Offices Concerning the Zakat as a Taxable-Income Deduction. International Journal of Zakat, 50-63.

Sugiyono. (2015). Metode penelitian pendidikan (pendekatan kuantitatif, kualitatif, dan $r$ \& d. Bandung: Alfabeta.

Syn, A. A., Ali, K. M., \& Hafidhuddin, D. (2018). Factors Affecting Palm Farmers' Decisions to Dispense Plantage-Product Zakat in Labuhanbatu Selatan Regency. International Journal of Zakat, 13-24.

Tuti, Cahyono, Mawardi, \& Mustofa. (2021). Optimizing zakat governance in East Java using analytical network process (ANP): the role of zakat technology (ZakaTech). Journal of Islamic Accounting and Business Research, 301-319.

U. H., B. J., H. M., \& K. S. (2021). The potential of Islamic social finance to alleviate poverty in the era of COVID-19: the moderating effect of ethical orientation. International Journal of Islamic and Middle Eastern Finance and Management, 0.

Zakat. (2011). Menggagas Aristektur Zakat Indonesia : Menuju Sinergi Pemerintah dan Masyarakat Sipil dalam Pengelolaan Zakat Nasional. Jakarta: IMS dan PEBS FEUI.

Zakat, B. A. (2020). Laporan BAZNAS dalam Penanganan Pandemi COVID19. Jakarta: Puskas : Baznas. 